KS. GINTER DZIERŻON

Uniwersytet Kardynała Stefana Wyszyńskiego w Warszawie

\title{
WYMOGI OBIEKTYWNE ORAZ SUBIEKTYWNE DOTYCZĄCE WSPÓLNOTY WPROWADZAJĄCEJ ZWYCZAJ PRAWNY, UJĘTE W KAN. 25 KPK
}

Treść: Wstęp. - 1. Zdolność wspólnoty do przyjęcia prawa. - 2. Zamiar wprowadzenia prawa przez wspólnotę. - Zakończenie.

\section{Wstęp}

W obszarze regulacji dotyczących zwyczaju prawnego (kann. 23 28 KPK) znajduje się kan. 25 KPK, w którym Ustawodawca sprecyzował warunki odnoszące się do wspólnoty wprowadzającej zwyczaj w systemie kanonicznym. Pierwszy z nich, mający charakter obiektywny, został zawarty w normatywnym stwierdzeniu, iż może to uczynić społeczność zdolna przynajmniej do przyjęcia prawa; drugi z kolei o walorze subiektywnym wiąże się z intencją, mianowicie, został on określony jako zamiar wprowadzenia prawa.

\section{Zdolność wspólnoty do przyjęcia prawa}

Wymóg obiektywny odnoszący się do wspólnoty skodyfikowany w kan. $25 \mathrm{KPK}$ w doktrynie po raz pierwszy w tej formie został sformułowany przez F. Suareza ${ }^{1}$. W takiej postaci został on przejęty przez Prawodawcę w kodyfikacji pio-benedyktyńskiej (kan. 26 KPK). W myśl kan. 25 KPK Tylko ten zwyczaj uzyskuje moc ustawy [...] który jest zachowywany [...] przez wspólnote zdolna przynajmniej do jego przyjęcia. Na marginesie należy dodać, iż z podobnym zwrotem normatywnym spotykamy się w kan. 29 KPK z 1983 r., dotyczącym dekretów ogólnych.

${ }^{1}$ Por. F. Suarez, Tractatus de legibus, Conimbricae 1612, s. 808-813. 
Tak sprecyzowane jurydyczne wymaganie stanowiło i stanowi przedmiot uwagi wielu kanonistów, którzy podejmują zamysł nad jego znaczeniem. W tym kontekście bowiem stają oni przed zasadniczym pytaniem: jaka społeczność kościelna spełnia warunek określony w kan. $25 \mathrm{KPK}$ ?

$\mathrm{Z}$ treści przytoczonego w pytaniu kanonu w pierwszym rzędzie wynika, iż wspólnota powinna posiadać zdolność receptywną pasywną ${ }^{2}$. Innymi słowy, to ona musi być adresatem prawa ${ }^{3}$.

W swych badaniach nad tym zagadnieniem J. Otaduy wykazał, iż zrównanie podmiotów pasywnych ustawy oraz zwyczaju wystąpiło po raz pierwszy w poglądach wspomnianego już F. Suareza, który twierdził, iż zwyczaj prawny jest ustawą ${ }^{4}$.

W tym kontekście należałoby zatem jeszcze raz zapytać: o jaką wspólnotę zatem chodzi w kan. 25 KPK?

Odpowiadając na tę wątpliwość, R. Sobański w swym komentarzu do kan. 25 KPK stwierdził: Na ten przymiot składa się homogeniczność i stałość odnośnej grupy społecznej, uznanej przez Kościót, majacej swoje sprawy wykraczajace poza dobro jednostkowe, co razem wzięte powoduje, iz wymaga ona własnych regulacji swoich spraw ${ }^{5}$. Podzielając tę opinię, J. Otaduy dodał, iż zwyczaj prawny związany jest $\mathrm{z}$ normami generalnymi, a nie $\mathrm{z}$ aktami poszczególnymi, które mogą zostać ustanowione przez społeczność o charakterze instytucjonalnym ${ }^{6}$.

2 Por. P. A. Bonnet, Annotazioni sulla consuetudine canonica, Torino 2000, s. 58; R. Sobański, Komentarz do kan. 25 KPK, w: J. Krukowski, R. Sobański, Komentarz do Kodeksu Prawa Kanonicznego, t, 1. Poznań 2003, s. 83.

3 Por. H. Socha, Allgemeine Normen, w: Münsterischer Kommentar zum Codex Iuris Canonici, t. 1, Essen 1985, ad 25, n. 6.

${ }^{4}$ Por. J. Otaduy, Comentario al can. 25, w: Comentario exegético al Código de Derecho Canónico, pod red. A. MarzoA, J. Miras, R. Rodríguez-Ocaña, t. 1, Pamplona 1996, s. 442.

5 Sobański, Komentarz do kan. 25 KPK, dz. cyt., s. 82 - 83; V. De Paolis, A. D'Auria, Le norme generali di Diritto Canonico. Commento al Codice di Diritto Canonico, Roma 2008, s. 178; Otaduy, Comentario al can. 25, dz. cyt., s. 443.

${ }^{6}$ Otaduy, Comentario al can. 25, dz. cyt., s. 443-444. Czytamy tutaj: „A nuestro juicio en este concepto están presentes dos valores de fondo. El primero de ellos es reservar la noción de costumbre para norma verdadamente generales (no singulares), que por lo tanto deben ser establecida por una comunidad suficiemente abstracta e institucionalidad, que trascienda las caracteristicas de los individuos que la componen". 
Należy jednak zauważyć, iż opinie kanonistów w tej kwestii są podzielone. Należy przypomnieć, iż w doktrynie przedkodeksowej autorzy rozważający ten problem dokonywali rozróżnienia pomiędzy społecznością doskonałą (societas perfecta), a więc wspólnota, na czele której stał autorytet wyposażony we władzę ustawodawcza, oraz społecznością niedoskonałą (societas imperfecta) niewyposażoną $\mathrm{w}$ taką władzę ${ }^{7}$ Z dociekań nad tym zagadnieniem przeprowadzonych przez G. Michielsa wynika, iż większość kanonistów klasycznych stała na stanowisku, że wymogi prawne w tym wypadku spełniają wyłącznie wspólnoty doskonałe (Innocenty IV, Joannes Andrea, Rochus Curtius). Swą argumentację opierali oni na założeniu, iż skuteczność prawna zwyczaju nie wynika z decyzji wspólnoty, lecz z woli prawodawcy ${ }^{8}$. Należy jednak zwrócić uwage, iż we współczesnej doktrynie tego typu założenie zostało odrzucone. Obecnie bowiem przeważa stanowisko ukształtowane zwłaszcza pod wpływem eklezjologii posoborowej, iż przyczyną sprawczą zwyczaju jest wspólnota wiernych'. W konsekwencji więc wymaganą prawem zdolność posiadają także wspólnoty niewyposażone w władzę ustawodawcza, lecz jedynie we władzę wykonawczą ${ }^{10}$; nieliczni natomiast autorzy uważają, iż określony w analizowanym kan. 25 KPK wymóg spełnia wyłącznie społeczność na czele której stoi autorytet posiadający władzę ustawodawczą ${ }^{11}$.

Według G. Comottiego, przeważający w doktrynie sposób wykładni wynika z treści analizowanej normy. Popierając tę tezę, stwierdził on, iż Prawodawca w jej treści użył przysłówka przynajmniej (saltem), wskazując, iż idzie o wspólnotę zdolną przynajmniej do jego przyjęcia ${ }^{12}$.

7 Szerzej na ten temat zob. L. ChiappettTa, Il Codice di diritto canonico. Commento giuridico-pastorale. t. 1, Roma 1996, s. 79.

${ }^{8}$ Por. G. Michiels, Normae generales iuris canonici, Lublin 1929, t. 2, s. 42.

9 Szerzej na ten temat zob. G. DzIERżon, Eklezjologiczne racje funkcjonownia zwyczaju prawnego w systemie kanonicznym, Prawo i Kościół 2 (2010), s. 45 - 55; R. SobAŃski, Nauki podstawowe prawa kanonicznego. Teoria prawa kanonicznego, t. 1, Warszawa 2001, s. 60.

${ }^{10}$ De Paolis, D’Auria, dz. cyt., s. 177-178.

11 Michiels, dz. cyt., s. 42: A. Vermeersch, J. Creusen, Epitome Iuris Canonici, Parisiis- Bruxellis 1937, s. 131: A. VAN Hove, De consuetudine. De temporis supputatione, w: Commentarium Loveniense in Codicem Iuris Canonici, vol. 1, t. 3, Malines - Roma 1933, s. 77.

12 Por. G. Сомотті, La consuetudine nel diritto canonico, Padova 1993, s. 135136: ,[...] l'avverbio saltem può farse conferire una ragione alla previsione codicisti- 
Podobną opinię wyraził F. Urrutia. W swej analizie tego problemu podkreślił on, iż zdolność, o której mowa w kan. $25 \mathrm{KPK}$, wiąże się ściśle $\mathrm{z}$ terminem lex stojącym w opozycji do innych norm takich jak $n p$. dekrety generalne czy statuty ${ }^{13}$. Rozwijając ten watek, H. Socha skonstatował, iż wymogu określonego w kan. 25 KPK nie można odnieść do: 1) statutów nieposiadających rangi ustawy (kan. $94 \S \S 1-2$ KPK; 2) dekretów generalnych (kann. 29 - 30 KPK; 3) poszczególnych aktów administracyjnych (kann. 35 - 95 KPK oraz 4) wyroków (kan.1607 KPK) ${ }^{14}$.

W tym kontekście we współczesnej kanonistyce powstaje wątpliwość co do zdolności wspólnot niedoskonałych. Dotyczy ona zwłaszcza małych społeczności wiernych. Otóż zdaniem większości kanonistów, tego typu społeczności spełniają wymóg ustalony w kan. $25 \mathrm{KPK}$. Poruszając ten problem, P. Lombardía podkreślił, iż takie zbiorowości również są zdolne do wprowadzenia zwyczaju, ponieważ będzie on w nich także zachowywany jako ustawa ${ }^{15}$. Z kolei J. Otaduy, zajmując się tym zagadnieniem, twierdzi, iż w odniesieniu do małych wspólnot należałoby mówić o zdolności relatywnej pozostającej w ściślej relacji do wprowadzanego typu zwyczaju. Taka społeczność bowiem posiada zdolność tylko we własnym obszarze normatywnym ${ }^{16}$.

\section{Zamiar wprowadzenia prawa przez wspólnotę}

Jak już wiadomo, Prawodawca w kan. 25 KPK ujął drugi warunek o charakterze subiektywnym, jakim jest intencja wprowadzenia prawa przez wspólnotę.

Rozpoczynając analizę tego zagadnienia, na wstępie należy zauważyć, iż w nowej kodyfikacji spotykamy się z nieco odmiennym ujęciem tej kwestii. W kan. 28 KPK z 1917 r. bowiem występowało sformułowanie a communitate cum animo se obligandi servata sit. Rozumienie

ca escludendo la necessitá che la communitá debba essere dotata di capacitas ferrendi leges".

13 Por. F. Urrutia, De normis generalibus.Adnotaiones in Codicem: Liber I, Romae 1983, s. 24-25; SocHA, dz. cyt., ad 25, n. 5.

14 Tamże.

15 Por. P. Lombardía, Commentario al can. 25, w: Codice di Diritto Canonico e leggi complementari, pod red. J. Arrieta, Roma 2007, s. 91.

${ }^{16}$ Otaduy, Comentario al can. 25, dz. cyt., s. 445. 
tego prawnego zwrotu nastręczało jednak ówczesnej doktrynie wielu trudności. Otóż komentatorzy przede wszystkim zastanawiali się, czy w przypadku wystapienia zwyczaju przeciwnego prawu konieczny był zamiar ze strony wprowadzających ${ }^{17}$, czy też wystarczał sam fakt niezachowywania prawa? ${ }^{18}$. Badając ten problem, G. Michiels wykazał, iż w kanonistyce dominowała opinia, zgodnie z którą konieczna była intencja uchylenia prawa (animus abrogandi legem) ${ }^{19}$.

Z przebiegu prac nad rewizją Kodeksu z 1917 r. wynika, iż zmiana normatywnego ujęcia tego zwrotu została jednomyślnie przyjęta przez konsultorow $^{20}$. Tym sposobem bowiem chciano uniknąć wattpliwości występujących u komentatorów Kodeksu z 1917 r. ${ }^{21}$. Trafnie zauważył P.A. Bonnet, iż poprzez modyfikację tego wymogu wprowadzono novum w podwójnym wymiarze, tzn. 1) odniesiono go do każdego typu zwyczaju oraz 2) uwydatniono aspekt przedmiotowy 22 .

Jak już wiadomo, obecnie w myśl kan. 25 KPK konieczny jest zamiar wprowadzenia prawa przez wspólnotę. Przy czym w tym kontekście dodaje się, iż dotyczy on nie tylko zwyczajów extra legem, lecz również zwyczajów contra legem ${ }^{23}$.

$\mathrm{Z}$ aspektu substancjalnego idzie zatem o pozytywny akt ${ }^{24}$ świadomy i wolny, odpowiadający swymi parametrami aktowi ludzkiemu ${ }^{25}$. Stąd

17 Za takim ujęciem opowiadał się m.in. P. Jone. Por. Commentarium in Codicem Iuris Canonici, t. 1, Padeborn 1954, s. 49. Autor ten stwierdził: „Cum intentio sese obligandi requiritur, non sufficit, ut fideles ponant aliquem actum, quia est moraliter bonus, sed ita genere debent desiderantes illum actum esse obligatorium [...]".

18 Szerzej na ten temat zob. Michiels, dz. cyt., s. 62 - 65; Vermeersch, Creusen, dz. cyt., s. 132-133: ,[...] intentio iusta, quae non erit frequens prodi potest incommodo quae admittuntur ad eam servandam, vel reprehensionem eorum qui eandem non servent".

19 Michiels, dz. cyt., s. 68.

${ }^{20}$ Por. Communicationes 15 (1984), s. 152. Zob. także. M. SAns GonzÁlez, La costumbre en la elaboración del Código de derecho canónico de 1917, w: La consuetudine tra diritto vivente e diritto positivo, pod red. M. Tedeschi, Soveria Mannelli 1998, s. $133-138$.

${ }^{21}$ Lombardía, Commentario al can. 23, dz. cyt., s. 91.

22 Bonnet, dz. cyt., s. 46-47.

23 De Paolis, D’Auria, dz. cyt., s. 180.

24 Por. García Martín, Le norme generali del Codex Iuris Canonici, Roma 1999, s. 147 .

25 Cомотті, dz. cyt., s. 136. 
też kanoniści wykluczają w tym wypadku skuteczność zamiaru podjętego pod wpływem przymusu i bojaźni ${ }^{26}$.

W tym miejscu należy zauważyć, iż z aspektu teoretycznoprawnego wprowadzenia zwyczaju nie należy ujmować w kategoriach aktu prawnego, lecz w kategoriach działania prawnego. Społeczność wiernych bowiem, podejmując inicjatywę, może określić przedmiot swego działania ${ }^{27}$. Zdaniem J. Garcíi Martína, dana grupa wiernych może to uczynić z dwóch powodów, jakimi są: uznanie niewystarczalności rozwiązań prawnych oraz uznanie za konieczne adaptowania danej normy do warunków danej wspólnoty ${ }^{28}$.

Rozwijając ten wątek, kanoniści zwracają uwagę, iż tego typu działania muszą mieć charakter publiczny oraz notoryczny. To znaczy, że muszą być one znane większości wspólnoty ${ }^{29}$. Ponadto w doktrynie przeważa teza, zgodnie z którą zamiar, o którym mowa w kan. $25 \mathrm{KPK}$, nie musi być powzięty przez wszystkich członków danej zbiorowości, lecz jedynie przez większą ich częśćc ${ }^{30}$. W literaturze wskazuje się, iż odosobniony podgląd w tej materii wyraził J. Piñero Carrrion, twierdząc, że w tym wypadku wystarcza mniejszośćc ${ }^{31}$.

W analizie tej kwestii zagadnieniem kluczowym staje się problem prawnej weryfikacji intencji. Autorzy zajmujący się tą tematyką podkreślaja, iż w tym wypadku wystarcza tzw. intencja interpretatywna ${ }^{32}$, a więc intencja, o której wnosi się racjonalnie $\mathrm{z}$ czynów dokonanych przez daną społecznośćc ${ }^{33}$ oraz z zachowań jej członków ${ }^{34}$. W tym kontekście R. Sobański trafnie skonstatował, iż w regulacjach kodekso-

26 Tamże, s. 137.

27 Szerzej na temat zróżnicowania pomiędzy kategoriami aktu prawnego oraz działania prawnego zob. G. DzIERżon, Niezdolność do zawarcia małżeństwa jako kategoria kanoniczna, Warszawa 2002, s. 26-36.

${ }^{28}$ García Martín, dz. cyt., s. 147: „[...] l'intenzione della communità dimostra la conoscenza dell'insuffcienza delle norme giuridiche e della necessità di adatare la norma giuridica alla realtà della communità".

29 Cомотті, dz. cyt., s. 137; Socha, dz. cyt., ad 25, n. 1.

30 De Paolis, D’Auria, dz. cyt., s. 178; García Martín, dz. cyt., s. 147.

31 Por. J. Piñero Carrrion, La ley de la Iglesia, Madrid 1985, s. 140.

32 VAN Hove, dz. cyt., s. 128-131.

33 Por. J. OtAduy, La comunidad como fuente de costumbre (presupuestos eclesiólogicos y sociales de la costumbre), w: Fuentes, interpretación, personas, Pamplona 2002, s. 158; BonNet, dz. cyt., s. 48.

34 SoBAŃSKI, Komentarz do kan. 25 KPK, dz. cyt., s. 83. 
wych nie mówi się nic o częstotliwości takich zachowań ${ }^{35}$. Przyjęcie skuteczności prawnej takiej formy intencji jest możliwe ze względu na fakt, iż tworzenie zwyczaju w systemie należy wiązać z kategorią czynności prawnych, wiążących się z precyzacją przedmiotu podjętego działania.

Należy też zauważyć, iż ocena zamiaru wprowadzenia prawa $\mathrm{z}$ natury rzeczy dokonuje się ex post ${ }^{36}$. Dlatego też już w doktrynie klasycznej wypracowano szereg praesumptiones hominis wiążących się $\mathrm{z}$ tym faktem. Dla przykładu twierdzono, iż z taką intencją mamy do czynienia wówczas, gdy ściśle określone zachowania są powtarzane przez członków wspólnoty przez pewien określony czas i mają na celu dobro wspólne danej zbiorowości ${ }^{37}$. Zdaniem kanonistów, nie spełniają zaś takich wymogów zachowania cechujące się oportunizmem, lekkomyślnością oraz całkowitym brakiem odniesienia do dobra wspólnego $^{38}$. W sensie negatywnym, jeżeli więc intencje nie miałyby na uwadze dobra wspólnego, to wtedy nie wywarłyby one skutku prawnego $^{39}$. Ponadto wskazuje się, iż nie powoduje następstw prawnych niezachowanie prawa wynikające z podstępu bądź też wypływające z pogardy dla prawa ${ }^{40}$.

W tym kontekście w kanonistyce rozważa się także problem możliwości powstania zwyczaju w dobrej bądź też w złej wierze. Na marginesie należy zwrócić uwagę, iż w przeszłości kwestia ta była szczegółowo rozpatrywana przez kanonistów przedkodeksowych, co doprowadziło do licznych kontrowersji ${ }^{41}$. Obecnie jednak większość autorów opowiada się za tezą, w myśl której zwyczaj może powstać jedynie w dobrej wierze. Według autorów komentarza Le norme generali di Diritto Canonico. Commneto al Codice di Diritto Canonico, zwyczaj nie może zostać wprowadzony przez wspólnotę w złej wierze. W ich przekonaniu taka sytuacja miałaby miejsce wówczas, gdy zachowania członków wspólnoty byłyby przeniknięte przebiegłością,

35 Tamże.

36 Comotti, dz. cyt., s. 157.

37 SuArez, dz. cyt., s. 834.

38 Comotti, dz. cyt., s. 158. De Paolis, D’Auria, dz. cyt., s. 178.

39 Bonnet, dz. cyt., s. 48.

40 De Paolis, D’Auria, dz. cyt., s. 179.

41 Szerzej na ten temat zob. P. Fedele, Il problema dell animus communitatis nelle doctrina canonistica della consuetudine, Milano 1937, s. 101. 
zarozumiałością bądź też wrogością w stosunku do prawa ${ }^{42}$. Uważają oni, że podjęcie działań przeciw prawu powinno wynikać z okoliczności usprawiedliwiających przyjęcie postaw antyjurydycznych oraz jeśli istnieją przyczyny wskazujące na nieużyteczność prawa bądź też jego niedostosowanie do kontekstu społecznego. Stąd też przyczyna jego wprowadzenia winna być słuszna i rozumna ${ }^{43}$.

Podobny podgląd wyraził F. Urrutia. Utrzymywał on, iż zła wiara nie może być przyczyną aprobaty zwyczaju przez ustawodawcę ani też nie może być nią zwycięstwo nieposłuszeństwa nad prawem. Rozwijając tę myśl, dodał on, iż prawodawca aprobuje zwyczaj nie ze względu na złą wiarę, lecz ze względu na jego rozumność ${ }^{44}$.

Ponadto, w doktrynie wskazuje się, iż konieczność podjęcia działań można wydedukowane $\mathrm{z}$ terminu legittime funkcjonującego $\mathrm{w}$ kan. 26 KPK odnoszącego się do zwyczaju otrzymującego moc prawa poprzez zachowywanie go zgodnie z prawem przez pełnych trzydzieści lat. Otóż w ich przekonaniu termin ten nie upłynie, jeśli zachowania członków danej społeczności byłyby przeniknięte złą wiarą ${ }^{45}$.

Kanoniści zajmujący się kwestią zamiaru wprowadzenia prawa przez wspólnotę podejmują także zagadnienie błędu. W związku z tym problemem rozróżniają oni dwie sytuacje: zwyczaj obok prawa oraz zwyczaj przeciw prawu. Wskazują oni, iż w pierwszej hipotezie członkowie danej społeczności są przekonani, iż dane prawo ich zobowiązuje, a rzeczywiście takie prawo nie istnieje; w drugim przypadku natomiast członkowie danej wspólnoty regularnie naruszają prawo, żyjąc w przeświadczeniu, że postępują zgodnie z prawem ${ }^{46}$. Uważają

${ }^{42}$ De Paolis, D’Auria, dz. cyt., s. 179.

43 Tamże. Czytamty tutaj: „Al contrario la buona fede é fatta salva se ci sono circostanze attenuanti o scusanti il comporatamento antigiuridico dei fedeli o se ci sono cause che fanno apparire le legge inutle o non adatta al contesto o agli usi della ragione, per cui la practica contra legem apparirà come iusta e ragionevole e porterà ben presto a far cadere in oblio la legge existente, per cui i comportamenti posti succesivamente nel tempo in violazione di legge sarano tenuti in bona fede".

44 URRUTIA, dz. cyt., s. 25. Autor ten stwierdził: „Mala fides non esset causa approbationis a legislatore, nec victoriam inoboedientiae supra legem implicaret formaliter loquendo, etenim legislator approbaret consuetudinem non propter malam fidem, sed propter rationabilitatem consuetudinis quae est eius nota intriniseca abstrahens a conscientia eorum qui usum praeferunt legi vigenti”.

45 De Paolis, D’Auria, dz. cyt., s. 179.

46 Tamże, s. 180. 
oni, iż powstały na skutek wadliwego działania zwyczaj nie uzyskuje skuteczności prawnej ${ }^{47}$. W tym kontekście przypominają oni, iż w kan. 28 KPK z 1917 r. funkcjonowała dyspozycja bardziej precyzyjna, zgodnie z którą zwyczaj obok prawa powinien być scienter zachowywany ${ }^{48}$.

Wreszcie należy dodać, iż G. Comotti rozważania dotyczące błędu, dobrej oraz złej wiary uważa za bezprzedmiotowe. Twierdzi on bowiem, iż tych kategorii nie można odnieść do wspólnoty samej w sobie, lecz jedynie do stanów psychicznych jej poszczególnych członków $^{49}$.

\section{Zakończenie}

Z przeprowadzonych analiz wynika, iż wymóg obiektywny dotyczący wspólnoty wprowadzającej zwyczaj skodyfikowany w kan. 25 KPK należy odnieść nie tylko do społeczności, na czele których stoi autorytet posiadający władzę ustawodawczą, lecz również do wspólnot wyposażonych jednie we władzę wykonawczą. Za takim rozumieniem przemawia m.in. wprowadzenie przez Prawodawcę w dyspozycji kan. 25 KPK przysłówka przynajmniej (saltem). Należy też dodać, iż tego typu teza opiera się również na przesłankach eklezjologicznych. W myśl bowiem współczesnej doktryny przyczyną materialną oraz formalną zwyczaju jest wspólnota wiernych.

W opracowaniu tym ponadto wykazano, iż zamiar wprowadzenia prawa przez wspólnotę powinien być aktem świadomym oraz dobrowolnym o charakterze publicznym oraz notorycznym. Powinien on zostać powzięty przez większość członków wspólnoty w dobrej wierze. Skuteczności prawnej zatem nie powodują działania podjęte w złej wierze lub pod wpływem błędu.

\footnotetext{
47 Tamże.

48 Tamże.

49 Cомотті, dz. cyt., s. 160. Autor ten stwierdził: „L'errore, l'ignoranza, la buona fede o la male fede non sono riferribili alla communità in se stessa, ma sono stati psicologici dei singoli $[\ldots]$ ”.
} 


\section{Objective and subjective requirements concerning the introduction of legal custom by a community included in can. 25 CIC}

In the presented article, the author focused his attention on the issue of objective and subjective requirements concerning the introduction of legal custom by a community included in can. $25 \mathrm{CIC}$. He pointed out that the objective condition concerning a community introducing a custom codified in can. 25 CIC should be related not only to communities whose head is an authority holding legislative power but also to communities with executive power only.

The author believes that this perception of the law is supported by the introduction into can. 25 CIC of the adverb at least (saltem). Moreover, he is convinced that this thesis is based on ecclesiological premises since according to the contemporary doctrine, the material and formal cause of a custom is a community of the faithful.

Another point made by the author is that an intention to introduce a law by a community should be a conscious and the voluntary act a public and habitual nature. It should be made by the majority of the community members in good faith. This means that error diriven actions or thouse made in bad faith do not acquire legal effectiveness. 